\title{
China And America: Partners In African Entrepreneurship
}

\author{
Kyle Usrey, (Email: kyle.usrey@friends.edu), Friends University
}

\begin{abstract}
In searching for ways to ameliorate the economic tension between the US and China over the $R M B$ 's valuation, a unique entrepreneurial partnership involving Africa is offered as a possible resolution.
\end{abstract}

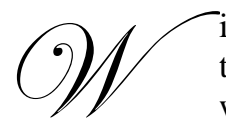

ith the attention of U.S. policy-makers divided between the protracted battles against Islamic terrorists in Iraq and political scandals at home, global economic issues until recently, particularly with China, seemed to have taken a backseat. As a result of a new initiative by Treasury Secretary Henry Paulson, two high-level "Strategic Economic Dialogues" over the last year (based on semi-annual meeting commitments from a September 2006 agreement between President Bush and Chinese President Hu Jintao) have centered on the ever-increasing economic ties between the two countries. And not surprisingly given the tension now in US-China economic relations, the main focus has been on the valuation of the Chinese RMB (Yuan), and in particular on how to reduce America's swelling trade deficits with China. Good thing, too, as the U.S. has to fund millions of dollars a day in debt service alone with China, leaving some people to think that the Chinese leaders meeting with American officials recently should have dressed in green qi paos, symbolic of landlord dominance in the pre-revolutionary era of China's past. Doubtless, China's emergence on the world stage will only lead to more intense competition and conflict unless U.S. policy-makers can find a strategy for cooperation. Maybe they should look to Africa, and begin to think of new paradigms of investment aid, based on privately-led, market entrepreneurism -- one field where Americans have led the world and for which China and America can be pragmatic partners in a new dynamic form of globalization.

"Opportunity cost" is defined as lost choices we could have made to use resources in other ways. While America is engaged in debating many issues of global leadership militarily and otherwise, what is not being discussed in Congress, over the airwaves, or across dinner tables are the monies and influence that weren't expended, but could have been, for different purposes and in different places in the world. Among America's many global obligations is its commitment to honor the U.N. Millennium Development Goals to halve global poverty by 2015. Presently, the U.S. provides only 0.17 percent of its GDP in foreign aid to the developing world, which is far behind its promise of 0.70 percent and next-to-last place among developed countries. Obviously, under current trends America will not meet this obligation in the next nine years amid huge fiscal deficits (projected to total well over \$2 trillion under even the rosiest assessments of the Bush Administration through fiscal year 2009, after inheriting a $\$ 128$ billion surplus in fiscal year 2001 from the Clinton Administration) and a trade deficit growing and breaking new records every year. (Almost a third of the 2006 U.S. \$763 billion trade deficit was with China alone; in fact, almost $\$ 500,000$ of net outflow in trade from the U.S. to China occurs every minute of every day, on the average, or $\$ 30$ million an hour).

Foreign entities already own half of America's $\$ 8.7$ trillion national debt. In November of 2006, China acknowledged what many international trade economists had calculated; they have attained over $\$ 1$ trillion in foreign currency reserves (estimates are that $70 \%$ of their holdings are in U.S. dollar-denominated notes, with over $\$ 340$ billion in T-Bills alone), surpassing Japan as the country with the most foreign-controlled U.S dollar reserves. By the May 2007 Strategic Economic Dialogue hosted by the US, China's reserves had reached $\$ 1.2$ trillion. One knee-jerk response from Congress has been to threaten a 27.5 percent tariff (based on a bill in the Senate by Senators Schumer and Graham) on all Chinese imports coming into the U.S. to penalize Beijing for undervaluing its currency. That threat continues to raise its hoary head with the new shift in Congressional power back to the 
Democrats, they may be even more demanding on the Chinese in resolving trade and currency imbalances - and the message is clear -- "either revalue the RMB or this tariff will be slapped on all imports from China". Even under the Republicans, Congress gave Beijing a window of time to show progress in alleviating this problem, by, showing some means of revaluing its currency.

Perhaps in partial response to the rising tide of animosity on this issue, The People's Bank of China (China's central bank) recently allowed the renminbi to trade within a wider band; in July of 2005, the band was allowed to vary from 0.3\%/day while in May of 2007, the band widened to allow trading of up to 0.5\%/day - all subject to Beijing's central bank's discretion, of course. (The RMB has appreciated approximately $8 \%$ since the 2005 announcement.) The People's Bank of China at the time of the 2005 revaluation policy also stated that exchange-rate appreciation could "play a role in addressing international payments imbalances" to help cool off China's overheated economy. The US Department of Treasury in June of 2007 announced that China's currency is undervalued, but did not go as far as declaring China a "currency manipulator", however. Congress, though, is in the mood to confront and blame China with almost twenty bills offered to punish China for its supposed role in causing America's trade deficit. Yet, the plain truth is that unless America changes its own macro-economics, very little will be done to satisfy Congressional, labor, and business trade protectionist hawks.

Without a doubt China holds a huge share of America's global trade deficit because of trade displacement, and that trade displacement is mostly throughout Asia, though. There is very little overlap between what little America manufactures (only $11 \%$ of the US economy is in manufacturing these days) and what China exports. If China's exports became more expensive, the US would simply switch to buying those products from other foreign companies and sources; there would be no net reduction in our global deficit, just a redistribution of it to other countries. The only way to fix that is to convince Americans to spend less and save more since China and other foreign countries are only selling what Americans want to buy in the quantities Americans demand. America's negative savings rate is the culprit according to many IT\&F experts, with no realistic prospect for reducing our trade deficit, regardless of the trade measures we might adopt or impose to limit imports from China.

Moreover, Chinese leaders won't be bullied into anything having to do with its currency evaluation. Chinese central bank officials privately note that they believe the RMB to be undervalued as well, but they don't know by how much (estimates among global economists range from 20-50\%); the Chinese central bank officials will allow it to appreciate slowly, at their own designated pace without marching to any other country's demands. Moreover, many world leaders think it would be foolish now for either the U.S. or China to aggravate the somewhat tenuous relationship between the twin engines of global economic growth. Instead, what seems to be occurring is a downward spiral of animosity and misunderstanding, leading to a potential trade war. This is where Africa can provide common cause to alleviate this geo-political conundrum.

\section{AFRICAN POVERTY}

Almost 1.2 billion people on the planet live on less than $\$ 1 /$ day, while over 2.8 billion, almost half the globe's population, live on less than $\$ 2 /$ day. Though $45 \%$ of the population in Sub-Saharan Africa lived on less than $\$ 1 /$ day in 1990 , that figure actually rose during the global boom ' 90 's to $46.4 \%$ in 2001 , with $32 \%$ of Africa's population below the minimal level of dietary energy consumption. Today over 300 million Africans (out of 800 million in population) live in abject poverty, despite the fact that a different 300 million people, mostly in China and India, on the planet came out of extreme poverty in the last decade (90's) of expansion and globalization. In stark contrast, there was a 30\% increase of poverty in the population in Sub-Saharan Africa. A June UN 2007 report prepared for the G-8 meetings in Germany stated the sub-Saharan Africa is behind schedule on its UN Millennium Development Goals. Although the percent of sub-Saharan Africans living on less than \$1/day has declined from $45.9 \%$ in 1999 to $41.1 \%$ in 2006, reaching the Millennium Goals means a doubling of that rate of decline. While experiencing an average $6 \%$ economic growth continent-wide in recent years, the growth is fragile according to the report, since it is largely driven by a boom in commodity prices; meanwhile, aid to sub-Saharan Africa had stayed virtually unchanged since 2004 , not counting one-off debt relief and humanitarian assistance. (This despite the fact that at the Gleneagles summit in 2005 world leaders promised to increase global aid to $\$ 130$ billion by 2010 , doubling it to Africa by that time to $\$ 50$ billion; yet, a recent OECD study in the Spring of 2007 found that donor 
countries in 2006 gave 5\% less in 2005 and in order to keep the promises of Gleneagles, giving will have to rise by $11 \% / y e a r$ between 2008 and 2010, faster than any other item of public spending among the 22 governments who dominate foreign aid globally. This doesn't take into account the intrusive, often cumbersome perceived need for donors to nose around in with 31 poor country governments having to receive almost 11,000 donor "missions", almost one a day, in 2005 alone, nor does it account for the often late-arrival of aid with only about $65 \%$ of arriving on schedule, according to the OECD. Indeed, sincere harmonization of governmental donor efforts with other benefactors and alignment with the priorities of the beneficiary countries is desperately needed.)

Moreover, foreign aid as a percent of Gross National Income in Sub-Saharan Africa has actually declined during the period of 1990 to 2003 from $6.4 \%$ to 5.9\% according to the World Bank. America's aid to Africa remains small, roughly equivalent to about $\$ 6 /$ African per year (1/30 of the amount of aid per capita that the US provides to Jordan, 1/20 economic assistance of aid per capita to Iraq, 1/13 per capita of aid to Israel, and 1/4 per capita of aid to Armenia, Bolivia, Macedonia, Georgia and many other countries), or about $1 \%$ of the America's Defense Department budget.

U.S. Official Development Assistance (USODA) through bilateral programs (like USAID, the Millennium Challenge Corporation, HHS, Department of State, Department of Agriculture, and other agencies), plus multilateral organizations to which the U.S. contributes (like the World Bank, IMF, African Development Bank and various United Nations bodies) is slightly over $\$ 4.3$ billion. President Bush has pledged to double aid to Africa by 2010 , with a $\$ 2.5$ billion increase in the Millennium Challenge Account, $\$ 1.5$ Billion more in the AIDS program (PEPFAR), and $\$ 500$ million in a recently announced malaria program. Recently at a G-8 meeting in Germany, he indicated a desire to even triple such assistance. In addition, the Bush administration pledged $\$ 674$ million for emergency famine relief in Africa in 2005. And in an international context, the G-8 in the last two years agreed to cancel the debt of eighteen of the poorest countries in the world. Nevertheless, even with President Bush's promises and the G-8 agreement to cancel debt, most experts agree that, in the absence of something completely new or different, the harsh reality of these noble financial commitments is that they are woefully insufficient.

Notwithstanding Warren Buffet's agreement last year to combine his considerable philanthropic resources with the mighty Gates Foundation, the total increase in annual outlays from their holdings will only amount to $\$ 1.5$ billion/year - and not all of it will be targeted to Africa. Clearly, even with the necessary support of NGOs and private enterprise, no adequate solution can be found without massive involvement of the private sector that doesn't also include some creative cooperation between China and the U.S.

\section{CHINESE TRADE AND INVESTMENT WITH AFRICA}

Meanwhile, under the radar, China has been investing heavily in Africa. From 2000 through 2005, ChinaAfrica trade almost quadrupled, growing at an annual rate of at least 30 percent a year. Trade between the two countries reportedly reached US\$50 billion for 2006, with expectations of doubling that by the end of the decade. China is now Africa's second largest trading partner, behind the United States. Net Foreign Direct Investment inflows from China to Africa also grew over 30 percent per year in the latest year-on figures. In the November 2006 Beijing summit of the Forum on China-Africa Co-operation (FOCAC), involving the heads of state and top officials of 48 of Africa's 53 countries, Chinese President Hu Jintao pledged to double China's aid to Africa by 2009 , by pledging US $\$ 3$ billion in loans, US $\$ 2$ billion in export credits, and a US\$5 billion fund to encourage Chinese investment in Africa, along with commitments to train 15,000 African professionals and open up to five free-trade ports. China's Premier Wen Jiabao at the same time called for efforts to boost trade to US $\$ 100$ billion by 2020, promising to open China's markets wider than ever to African exports.

Within the framework of the forum dating back to 2000, China forgave almost 11 billion yuan or US\$1.4 billion in debts of 31 lesser-developed African countries. Additionally, zero tariff treatment was granted on commodities from 28 African countries, while helping 40 African countries to construct over 900 projects and providing 58 preferential loan projects in 26 different countries. Chinese companies have been engaged in all sorts of infrastructure projects, building hospitals, highways, waterworks, schools, and even sports arenas. All told, there are about 900 investment projects on the African continent financed with Chinese money, with Chinese investment 
reaching over US\$6.25 billion. And it's estimated that the Chinese diaspora in Africa totals over 80,000 workers and businessmen.

No question that much of China's trade with Africa involves importing Africa's natural resources (timber, oil, diamonds, copper and aluminum) and raw materials in exchange for manufactured goods. China, for example, imported 38 million tons of crude oil, over $30 \%$ of its total oil imports in 2005. Just this year, Angola overtook Saudi Arabia as the biggest oil exporter to China. This trade pattern has created a bit of a backlash among some countries, especially Zambia, as it smacks of neo-colonialism, but the World Bank among others is keen on introducing the "Chinese model" of development growth and quasi-capitalism to the continent. China has responded to criticism of its aggressive trade for raw materials in Africa with a State Council document entitled "Nine Principles" to warn Chinese businesses in Africa about any abusive behaviors. In the last few months, China has made huge trade and investment deals with Ghana, Kenya, Sudan, Nigeria, Ethiopia, Angola, South Africa, Tanzania, the Republic of the Congo, Uganda, and many others - and not all around tying up oil resources.

Compare America's efforts in Africa: The total net investment from the USA into Africa for the latest reported quarter was just $\$ 573$ million. President Bush's commitment to double aid to Africa by 2010 to about $\$ 10$ billion is nowhere near meeting America's UN Millennium Development Goals commitment to African poverty relief; the only way that could possibly happen is to combine resources, public and private ventures, with China in a special way. (Over a year ago, President Bush and President Hu from China met in an ill-fated visit in Washington; neither Bush nor Hu announced any new agreements or initiatives, instead mouthing mere pyrrhic pledges to work together on trade and currency issues with each calling for a level playing field for business and investments in the other's country. Perhaps, as one expert suggested, the focus was too much on bilateral trade and investment issues, and not enough on poverty alleviation in a global -- maybe African -- context.)

\section{AFRICA'S POVERTY TRAP AND A POSSIBLE SOLUTION}

Clearly, traditional means of financial foreign aid or debt relief are not the sole answer to Africa's poverty trap. Stories and studies of wasted foreign aid to governments in Africa are legion. (According to one report by the Heritage Foundation, between 1980 and 2003, America doled out almost $\$ 120$ billion in foreign aid to 89 countries; thirty-seven of them, mostly in Sub-Saharan Africa actually became poorer. Another study shows that almost $\$ 15$ billion/year pours out of Africa.) As fast as aid comes in, almost the same amount of capital flows out to Western banks.

Perhaps it's time for the U.S. and China to partner in "co-opetition" (competition and cooperation) in investing in Africa beyond our existing forms of aid for infrastructure, natural resource acquisitions, and health and human services. Indeed, the next war for ideas, hearts, and minds will probably be in Africa, a continent split between Islam and Christianity, a continent that harbors too many failed states to count, and a continent that frankly could provide new markets, new paradigms, and new opportunities for all of us if only the worlds two leading economic powers would make a commitment to partner proactively there.

"Poverty is the worst form of violence," according to Gandhi. Economist Jeffery Sachs states that eight million people die every year because they are too poor to live. With thirty-four out of the forty-eight of the world's poorest countries, Sub-Saharan Africa faces levels of rural poverty surpassed only by urban slum poverty. Bishop Tutu at the recent World Council of Churches Ninth Assembly Congress in Brazil stated that the war on terror will not be won as long "as poverty, squalor, ignorance and disease make God's children, members of our family, desperate." Knowing that the human race is all one family, he continued, how can it be that "a small fraction of budgets in [developed countries] would [be all that's necessary to] ensure that all God's children everywhere would have enough to eat, clean water to drink, affordable health care, decent homes and a good education."

While China and America race to secure traditional trade and investment in Africa, a new component of the private sector holds the key to real change and progress. America and China should focus on developing entrepreneurs and a spirit of entrepreneurship in Africa among its peoples. The recent spotlight on Nobel Peace Prize recipient, Muhammad Yunus, a Muslim, and his work in building Grameen Bank in Bangladesh as a micro- 
finance institution (MFI) points to the new models of harnessing the market to help solve social problems of poverty and low growth at the grass roots level. MFI and its progeny micro-enterprise development (MED), which entails intensive business development on top of micro-loans, are a recent phenomenon of the last 25 years, but their successes throughout the globe have been well-documented and studied. Grameen Bank has helped over 6 million Bangladeshis out of poverty. A number of organizations, including Opportunity International, started by David Bussau, a Christian and hailed as the "grandfather of micro-enterprise development," were found in a recent British university study to have lifted over 10 million people worldwide out of extreme poverty over the last ten years. By one reliable estimate, Bussau's various MED organizations and their progeny create a new job every minute somewhere in the world; his organizations operate in over 60 countries, even in North Korea.

Clearly, entrepreneurship through MFI and MED is a development marvel not limited to one faith or one country or region. A recent study by the Kauffman Foundation in the Global Entrepreneurship Monitor (GEM) places America near the top of countries in providing "opportunity entrepreneurship." Opportunity entrepreneurship is where individuals seize an opportunity by choice, not necessity. Another GEM report places China in the top ten of all countries in terms of "necessity entrepreneurship," which is defined as those engaged in entrepreneurism because they have no better choice for work.

So, what's the possible connection between China, America, and Africa? Chinese leaders and students can help provide the basic survival entrepreneurial skills accompanied by needed capital for Africans to finish the process of lifting themselves out of abject poverty. Americans, whether they be MBA students, economic development experts, corporate leaders, or even parachurch organizations can help African entrepreneurs take the next step to "mezzanine-level" businesses capable of scale and competing on an international field. Moreover, the possible power of Chinese/American teams of entrepreneurs should lead to dramatic results of millions of Africans creating for themselves a new means of not just survival, but economic clout -- from the ground up, as opposed to the traditional model of top-down delivery of aid.

One might readily ask, "What's in it for China to do this?" Development experts point out that China cannot provide world-class technology, management know-how, or the international market depth that Americans can. Moreover, China itself has hundreds of millions of people, mostly in rural areas suffering the pangs of extreme poverty. Why wouldn't it take some of this $\$ 1$ trillion and invest in wiping out poverty inside its own borders. First, it is estimated by astute international economists that China only needs about $\$ 600$ billion in reserves as a safeguard against potential shocks to its steaming economy (the rule of thumb is a country needs enough foreign exchange for three months of imports or to settle its short-term foreign debt and China has over five times the coverage for imports and six times its short-term debt requirements), leaving over $\$ 600$ billion that could be transferred to a sovereign fund for external uses. Secondly, China's economy is in danger of over-heating with growth rates of almost 11 percent/year, so China's economy technocrats must be careful of pumping too much liquidity into the economy and at once risking higher inflation, asset price bubbles and even more sloppy bank lending. Even if China used some of its reserves to buy oil or other commodities, stockpiling would probably push up prices quickly and might push markets into potential turmoil (i.e. if China invested just 5 percent of its reserves in gold, it could buy the world's entire annual production, thereby probably creating a price bubble in gold; imagine what might happen with China stockpiling oil from its excess foreign reserve stash). China's investment in infrastructure is over 40 percent of its GDP already, stretching its bounds. Even injecting money into weak pension systems or improving health care requiring conversion into yuan would put upward pressure on the yuan, thereby forcing the central bank to buy more dollars to hold it down.

China has begun investing some of its $\$ 600$ billion in excess reserves already internationally, utilizing a fund management approach via a government investment authority similar to Singapore's use of liquid resources for strategic investment. And even some of that money is reaching the US in Beijing's attempt to diversify its foreign reserve holdings and obtain higher returns, with the announcement in May of 2007 that China, through its state-run investment company, became a $\$ 3$ billion equity investor in Blackstone as part of Blackstone's \$7 billion IPO campaign. This investment coupled with a similarly-timed announcement of Chinese plans to buy $\$ 4.3$ billion of US Technology, really is just a drop in the bucket, though, for China since the World Bank estimates it will run a $\$ 250$ billion trade surplus in 2007. While China's potential foreign dollar reserves investments are so large that they 
move markets, perhaps the ability to move the anti-poverty market in Africa with the U.S. as a strategic partner would be the most attractive geopolitical public relations gambit in China's ongoing desire for global respect, thereby being seen as an "investment" with expected high social/geo-political returns in the near future with the promise of long-term economic gains for the entire planet.

In short, China and America have much to gain in cooperating to provide significant capital, infrastructure development, and support for entrepreneurial growth to Africa - not to mention what it can mean for helping African people lift themselves out of poverty. (America, of course, through USAID and other organizations, has had some experience in funding and developing micro-enterprise entrepreneurs in the developing world, including some dramatic successes in the Philippines and parts of South Asia. According to the president of the Kauffman Foundation, Carl J. Schramm, in today's international marketplace, America's unmatched advantage is entrepreneurship; it's an infinitely renewable resource, essential to America's success in the world. After all, most new jobs and technologies nowadays come from entrepreneurial companies, and well over half of university graduates will someday start a business of their own. What better way to exploit America's most competitive market know-how than by exporting it to those in greatest need.)

In many ways, this China-U.S. partnership proposal is a new type of Peace Corps. The Peace Corps, initiated in the 1960s by President Kennedy, has had a long legacy of service to developing countries, but it may be time to revise and redirect it. It has come under some sharp criticism for its latent attempts to replicate Americanstyle prosperity and democracy together with some serious dissonance with the complicated realities confronted by many in lesser-developed countries. After all, the Peace Corps was created in the midst of the Cold War, designed in part to show an alternative to Communism by providing a general focus on spreading American goodwill and service to the developing world. In this day and age, "globalization" has replaced the Cold War paradigm, and the need for focused poverty alleviation and market development demands something more intensive: an "Entrepreneurial Corps" as a specialized arm of the Peace Corps. Indeed, many Peace Corps projects entail some form of basic economic development, but a focused entrepreneurship strategy with specialized business and economics training could be the final tool to fully leverage the private sector in synergizing sustainable economic growth in Africa. Business school graduates, professors, and business and government leaders could follow the model of physicians, nurses, teachers and other professionals in donating a few years of their lives to developing MFI and MED models in entrepreneurship. And there's no better place to begin than Africa in a multi-lateral partnership with China, asking China to contribute \$20 billion in US dollar-denominated reserves per year through 2015 (almost $\$ 200$ billion total over nine years with interest.

In essence China would be transferring current account and fiscal deficit obligations from America to SubSaharan African countries -- as investments in entrepreneurship, with America sharing its knowledge capital and combining technical assistance with China's unique talents. ( $\$ 20$ billion/year from China, although immense in size such that in comparison it is in excess of all the soft dollar loans made available by the World Bank, EBRD, and the African Development Bank combined, is nonetheless just average one-month's trade deficit with the USA, and merely the annual interest accumulating on China's $\$ 1.2$ trillion and growing reserves.) Indeed, to paraphrase Britain's Prime Minister Gordon Brown, instead of looking to what we could do to or for Africa, we must know that now "in this century, the issue is what Africa empowered can do for herself." And that means Africa empowered anew via the Entrepreneurship Corps.

What do we have to lose? A whole continent, and more. What do we have to gain? A structured partnership based on the strengths of both China and America that, admittedly, won't be easy, but which could form the basis for a new paradigm of economic development that might obviate some of the problems the world is facing now in the Middle East. Opportunity cost? We can't afford not to!

\section{ENDNOTES}

${ }^{1}$ The Chinese policy of keeping the Yuan pegged to the dollar at a time when the Yuan would appear to be seriously undervalued has a number of impacts on US economic interests: 1) prices of all exports to China are higher (in Yuan) than they would be with a revalued Yuan, likely reducing the amount of Chinese imports of all foreign goods and services 
including those from the US. Yet if the Chinese were to revalue the Yuan, it is not at all clear that US exports to China would increase all that much. This is because a revalued Yuan would make all their imports, not just those from the US, cheaper. Further, with the US economy now at or slightly above full employment level of GDP, the US is not in a position to expand production much to increase sales to China; 2)the currently undervalued Yuan makes US imports of goods and services from China cheap. This is an enormous benefit to US consumers and it also benefits US businesses, including manufacturers, who use Chinese-made components in their manufactured goods; 3 ) the huge balance of payments surpluses that China is having are being accumulated in their international reserve holdings, much of which are held in US government treasury bonds. With this huge amount of annual lending to the US government (about half the US government's deficit in recent years has been financed by loans from China), US interest rates are significantly lower than they would otherwise be, given the US inability to balance its federal government budget. These lower-than-otherwise interest rates are a benefit to all US businesses and consumers who are saving substantially on the cost of credit. Indeed, some economists see a hidden "deal" with China - China finances American deficits with money it gets from exports; otherwise, the dollar would weaken even further, lowering the value of China's dollar reserves. The undervalued Yuan may indeed harmful to the Chinese economy, though. Real GDP surged at about $11 \%$ for 2006 and industrial output grew at a record $19.5 \%$ year-on-year in June, thereby creating the specter of an over-heated economy. Coupled with money growth supply approaching $30 \%$ this year, China may have no choice but to introduce monetary tightening measures because a failure to do so could lead to an eventual investment downturn. China's private consumption sector of its economy dropped to just 38\% of GDP in 2005, below what many economists feel would be a healthy rate of at least $50 \%$.

${ }^{2}$ The February 2006 USTR report, "U.S.-China Trade Relations: Entering a New Phase of Greater Accountability and Enforcement (Top to Bottom Review)" deals almost exclusively with the bilateral US-China trade relationship; very little addresses possible cooperative arrangements to enhance trading regimes outside of the bilateral impacts. The only aspirational language in the document that makes tangential reference to possible creative options is located on page 11, "More broadly, we also believe that China has now clearly ascended to the ranks of global trading powers who - like the United States, European Union and Japan - must assume responsibility not only to fulfill commitments, but also go beyond them to ensure the continued health of the global trading system." (Emphasis supplied) No reference whatsoever is made to Africa in this report.

${ }^{3}$ One other goal of such a partnership might be to ensure that China does not underwrite rogue regimes that may seek to undermine the security and stability of the international community. America has had some experience in such a partnership in the past through the Colombo Plan for Cooperative Economic and Social Development in Asia and the Pacific. The Colombo Plan is a collective intergovernmental effort toward the economic and social development of member countries in the Asia-Pacific region, by providing a forum for the discussion of development needs of member countries, especially those that are LDC's, and the implementation of programs in response to these identified needs. The Plan encourages developing member countries to become donors themselves and participate in economic and technical cooperation among their sister developing countries. The main focus of all Colombo Plan activities has been human resource development, to promote technical cooperation, to "assist in the sharing and transfer of technology among member countries", and to "keep under review relevant information on technical co-operation between the member governments...".

${ }^{4}$ The "Seattle Initiative for Global Development," launched in 2003 by many American corporate and former American government leaders states that eliminating extreme poverty globally for those who live on less than $\$ 1 /$ day is within our reach. What's required is increasing public and private funding from US financial sources by $\$ 20$ billion/year to reach America's Millennium Goals, through investment in education, health, good governance, and most importantly, economic opportunity for poor individuals in developing countries. Interestingly, some economists have estimated that a floating yuan would cut the US's trade deficit with China by about $\$ 20$ billion/year as well. The People's Bank of China made over a \$20 billion profit last year, more than any other of the world's banks, mostly on net interest income.

\section{BIBLIOGRAPHY}

1. Acs, Zoltan J., Pia Arenius, Michael Hay and Maria Minniti. GEM 2004 Global Report, Global Entrepreneurship Monitor, May 27, 2005.

2. Alden, Chris. Leveraging the Dragon: Toward An Africa That Can Say No, Yale Global Online, March 1, 2005. 
3. Altman, Daniel. A Stickier Trade Gap, The New York Times, March 26, 2006.

4. Altman, Daniel. As the Dollar Falls, Some Dominoes Don't, The New York Times, December $10,2006$.

5. Atlas, Terry, ed. Human Rights and Human Nature, U.S. News \& World Report, March $20,2006$.

6. $\quad$ Balfour, Frederik. One Foot in China, Business Week, May 1, 2006.

7. Beach, William W. A Way to Test-Drive Tax Policy, Business Week, March 13, 2006.

8. Beattie, Alan and Eoin Callan. Chinese Lending Creating New Wave of Hidden Debt in Africa, IMF says, Financial Times, December 8, 2006.

9. Beattie, Alan and Richard McGregor. New-model Nation: Why China Faces Fresh Tasks on Trade, Financial Times, December 11, 2006.

10. Bijian, Zheng. China's Peaceful Rise to Great Power Status, Foreign Affairs, Sept/Oct 2005.

11. Black, Richard ad Howard White, ed. Targeting Development: Critical Perspectives on the Millennium Development Goals (Routledge, 2006).

12. Broder, David S. Gleam Amid the Gloom, The Washington Post, May 15, 2005.

13. Bush, Dana and Robin Oakley. Bush, Blair Push African Debt Relief, CNN.com, June 8, 2005.

14. Callan, Eoin and Krishna Guha. US trade Chief Says Ties strained by Pace of Reforms in China, Financial Times, December 11, 2006.

15. Cantwell, Maria and Patty Murray. Letter: A New Strategy for Global Development, United States Senate, February 27, 2004.

16. Clapp, Bill and Dan Evans, Bill Gates, Sr. and Bill Ruckelshaus. Eliminating Global Poverty is Job One, Seattle Post-Intelligencer, March 17, 2004.

17. Cooper, James C. A Ray of Hope for the Trade Gap, Business Week, May 29, 2006.

18. Coy, Peter. Why Free-Trade Talks are in Free Fall, Business Week, May 22, 2006.

19. Crutsinger, Martin. Foreigners' Share of America Growing, Spokesman-Review, March $20,2006$.

20. De Mesquita, Bruce and George W. Downs. Development and Democracy, Foreign Affairs, Sept/Oct 2005.

21. De Soto, Hernando. Letter to The Honorable Daniel J. Evans, Instituto Libertad y Democracia, March 19 , 2004.

22. Dickie, Mure. China Could Allow Renminbi a Wider Daily Trading Band, Financial Times.

23. Emmott, Bill. Letter to Seattle Initiative Founders, The Economist, August 2, 2004.

24. Fang, Bay. Raising the Stakes on China, U.S. News \& World Report, December 18, 2006.

25. Fang, Bay. Stacking the Deck, U.S. News \& World Report, April 24, 2006.

26. Forbes, Steve. These Numbers Don't Figure, Forbes, January 29, 2007.

27. Garnham, Peter. China Forces Dollar into the Spotlight, Financial Times, November 12, 2006.

28. Garnham, Peter. China’s Reserves Exceed \$1,000bn, Financial Times, November 7, 2006.

29. Gross, Daniel. Invest Globally, Stagnate Locally, The New York Times, March 2006.

30. Guha, Krishna and Mure Dickie. US and China to Step Up Talks on Services, Financial Times, December 17, 2006.

31. Guha, Krishna and Richard MacGregor. Dialogue with Beijing Will Lock in Economic Liberalism, says US, Financial Times, September 21, 2006.

32. Guha, Krishna and Richard McGregor. China and US Set Up Regular Top-level Dialogue, Financial Times.

33. Gupta, Sanjeev, Catherine Pattillo, and Smita Wagh. Are Donor Countries Giving More or Less Aid?, International Monetary Fund, January 2006

34. Higgins, Will. Business and Civic Leaders Hear Appeal for Foreign Aid, The Indianapolis Star, May 6, 2005.

35. Holman, Michael. Africa Must Help Itself, Spokesman-Review

36. Huang, Yasheng. Beijing can learn from Zhejiang's rural entrepreneurs, Financial Times.

37. Kirby, Carrie. Group Fights Global Poverty, San Francisco Chronicle, July 15, 2005.

38. Kristof, Nicholas D. China and Sudan, Blood and Oil, The New York Times, April 23, 2006.

39. Krowitz, Edward. China's Reserves: Golden Dragon or Sitting Duck, China Daily, June 7, 2007.

40. Lijun, Wang and Zhou Shijian. Forcing Fast RMB Rise Will Be Lose-Lose Situation, China Daily, June 5, 2007.

41. Mallet, Victor. Hunt for Resources in the Developing World, Financial Times, December 12, 2006. 
42. Malpass, David. The Triple Deficit Paralyzes Policy Vision, Forbes, January 29, 2007.

43. McDonald, Joe. China's Trade Surplus Surges 73 Percent, AP June 11, 2007.

44. McGregor, Richard and Krishna Guha. US Cranks Up the Decibels While China Plays It Cool, Financial Times, December 12, 2006.

45. McGregor, Richard. China to Beef Up Exchange Trading, Financial Times, December 13, 2006.

46. McGregor, Richard. Sino-African Summit Ends with Aid Pledges and Swipe at Critics, Financial Times, November 6, 2006.

47. Mehring, James. Less Foreign Capital Than Meets the Eye, Business Week, February 27, 2006.

48. Minniti, Maria, with William D. Bygrave and Erkko Autio. GEM 2005 Executive Report, Global Entrepreneurship Monitor, January 12, 2006.

49. Mitchell, George J. Letter to Seattle Initiative for Global Development, Piper Rudnick, March $26,2004$.

50. Mogollon, Mery and Chris Kraul. Venezuela, Iran to create joint investment fund, The Spokesman-Review, January 14, 2007.

51. Morris, James. Letter to Seattle Initiative for Global Development, World Food Programme, August 20, 2004.

52. Nilekani, Nandan M. The CEO of Infosys on Obstacles to Innovation in China and India, IN, September 2006).

53. Pan, Esther. China, Africa, and Oil, Council on Foreign Relations, January 12, 2006.

54. Plott, David. Review of Beyond Liberal Democracy: Political Thinking for an East Asian Context, by Daniel A. Bell. Review

55. Porter, Eduardo. China Wins Over Washington, But D.C. Proves a Bit Tougher, The New York Times, April 23, 2006.

56. Radelet, Steve and Bilal Siddiqi. US Pledges of Aid to Africa: Let's Do the Numbers, Center for Global Development, July 2005.

57. Reynolds, Paul D., William D. Bygrave, Erkko Autio and Michael Hay. GEM Global 2002 Executive Report, Global Entrepreneurship Monitor, November 13, 2002.

58. Reynolds, Paul D., William D. Bygrave, Erkko Autio and others. GEM Global Report 2003, Global Entrepreneurship Monitor, March 15, 2004).

59. Ruckelshaus, Bill. Raising Living Standards, The New York Times, January 12, 2005.

60. Saminather, Nichola. Why the Gap Won't Stop Growing, BusinessWeek, September 25, 2006.

61. Samuelson, Robert J. Why the Buck Is on the Edge, Newsweek, December 11, 2006.

62. Schwab, Susan. Chinese Voices that Oppose Reform Grow Louder, Financial Times, December 11, 2006.

63. Shalikashvili, John and Bill Clapp. Lifting Millions of People Out of Grinding Poverty, The Seattle Times, February 7, 2005.

64. Southey, Caroline. Chinese tycoon buys $\$ 800 \mathrm{~m}$ stake in Anglo American, Financial Times, November 12 , 2006.

65. Stamp, Mary. Bishop Envisions United World, Spokesman-Review, February 22, 2006.

66. Stiglitz, Joseph E. How to Fix the Global Economy, The New York Times, October 3, 2006.

67. Subler, Jason. U.S. urges China to Speed Up Economic Reforms, Reuters, September 20, 2006.

68. Tassell, Tony. China's Forex Diversification Plan Piles the Pressure on Greenback, Financial Times, November 10, 2006.

69. United States Trade Representative. U.S.-China Trade Relations: Entering a New Phase of Greater Accountability and Enforcement, Executive Office of the President of the United States, February 2006.

70. Worship, Patrick. Africa Falls Behind on Poverty Goals, U.N. says, Reuters June 6, 2007.

71. Weisman, Steven R. Paulson Reinforces His Reach, The New York Times, August 10, 2006.

72. Wolf, Richard. Spending Explodes Under GOP, USA Today, April 3, 2006.

73. Wolfowitz, Paul. Paul Wolfowitz Remarks: Trade - the Missing Link to Opportunity, The World Bank, December 7, 2005.

74. Zakaria, Fareed. Adrift in a Turbulent World, Newsweek, April 24, 2006.

75. Zukerman, Mortimer B. (ed.). The case of the 12 Zeros, U.S. News \& World Report, March $21,2005$.

76. Zweig, David and Bi Jianhai, China's Global Hunt for Energy, Foreign Affairs, Sept/Oct 2005.

77. _ _ Big Guns, Small Prizes, The Economist, December 23, 2006. 
78. - Building a Better World: A New Global Development Strategy to End Extreme Poverty, Initiative for Global Development, January 2004.

79. _ C C C C C C 2006.

80. C. China to Invest \$3 B in Blackstone, CNN.com May 21, 2007.

81. Is China a Currency Manipulator?, The Week, May 26, 2006.

82. Luok, Hu's Buying Oil From Nigeria, U.S. News \& World Report, May 8, 2006.

83. - Never Too Late to Scramble, The Economist, October 28, 2006.

84. - On Safari, The Economist, November 4, 2006.

85. _ Paulson's Party, The Economist, December 9, 2006.

86. Foreign Aid: The Non-Aligned Movement, The Economist April 7, 2007.

87. _ Who Wants to Be a Trillionaire?, The Economist, October 28, 2006.

88. Wrong Model, Right Continent, The Economist, October 28, 2006.

89. _ C C C C C _ Jina Jan FDI Up 11 pct from Year Earlier, Reuters, South Africa, February 20, 2006.

90. _. Congressional Budget Justification FY 06: Africa, USAID, June 14, 2005.

91. _ Development Co-operation Report 2005, Organisation for Economic Co-operation and Development, February 2006.

92. _ _ FDI Net-Inflows to Developing Countries for 2003, Invest In China, November 26, 2005.

93. ㄴ. Mini-Atlas of Millennium Development Goals: Building a Better World, World Bank, 2005.

94. — Ranking the Rich 2004, Center for Global Development, May 2004.

95. _ Sub-Saharan Africa Country Profile, The World Bank Group, World Development Indicators database, April 2004.

96. ㄴ. Sub-Saharan Africa Data Profile, The World Bank Group, World Development Indicators database, August 2005.

97. _ _ The Millennium Development Goals Report 2005. United Nations, 2005.

98. UN Millennium Project 2005: Investing in Development: A Practical Plan to Achieve the Millennium Development Goals. Overview. United Nations, 2005.

99. _. _ China's Scramble for Africa Finds a Welcome in Kenya, Financial Times, August 10, 2006. 